\title{
SITUATIONAL MANAGEMENT OF INTEGRATED FLIGHT PREPARATION AND TRAINING OF PILOTS AS AN EDUCATION SERVICE

\author{
Pavol Petríček ${ }^{1}$, Stanislav Szabo $^{2}$, Róbert Rozenberg ${ }^{3}$
}

\begin{abstract}
This article examines the situational management of the Knowledge Alliance of Aviation Education as an Education Service in the conditions of the Slovak Republic. It is the second part of our study. In order to ensure the continuity, quality and safety in the aviation education of future military and civil pilots as aviation professionals, research works of a similar nature are needed. This article uses analysis and synthesis tools, the method "per partes" (integration in parts) with the potential to apply the situational management method in the aviation practice and the expert method. Authors solved the following praxeological questions: What does situational management mean in the education and training of pilots? What are the sources of knowledge and good practice in the management of education and training of pilots? Which control processes can we use for the efficient management of education and training of pilots as a complex aviation system? The output of the article is the proposal of situational management of the comprehensive system of education and training of pilots with the support of evolutionary and cooperative management in the aviation practice of state-private entities.
\end{abstract}

UDC Classification: 378, DOI: 10.12955/cbup.v7.1419

Keywords: situational management, service, safety, education, knowledge alliance, aviation

\section{Introduction}

In order to ensure continuity, quality and safety in the aviation education of future military and civil aviation professionals, research works, especially the doctoral thesis, of a similar nature are needed. Our study is divided into several parts. This article presents the second part of our study on the Knowledge Alliance of Aviation Education. Aviation education has a much wider meaning than just the education and training of pilots. The updated content of integrated flight preparation and training of pilots respects a new description, the study field "Transportation", led by the Dean of the Faculty of Aeronautics Assoc. Prof. Stanislav Szabo.

The main objective of this article is to create a proposal for the application of situational management of the Knowledge Alliance of Aviation Education as an Education Service in the conditions of the Slovak Republic for the realization of goals in the field of education and training of Air Force Pilots of the Slovak Armed Forces. The problem solvers propose the implementation of appropriate tools for the management of educational processes by using the knowledge of situational management of complex technical systems as studied by Madarász (2003) in their scientific work.

We have the following praxeological questions: What does situational management mean in the education and training of pilots? What are the sources of knowledge and good practice in the management of education and training of pilots? Which control processes can we use for the efficient management of education and training of pilots as a complex aviation system? Our assumption is that for the needs of a state such as the Slovak Republic, for the continuous training of pilots as professionals, the optimal solution is the application of situational management of state-private cooperation and partnership as a service of the Knowledge Alliance of Aviation Education.

\section{Literature review: the new education content of Knowledge Alliance for situational management}

The subjects of situational management application are the core elements of new education and training of pilots as a part of the Knowledge Alliance of Aviation Education and as the education service presented in the Table 1.

The results of the theoretical work and the scientific and research activities in the field of: University Academic subjects, Social and Human Sciences, the Simulation and modelling of Security issues, the Applied Technical Sciences, the Applied Civil and Military / Air Force management, education and training etc. within the Expert Database of Civil and Military Aviation Experience in progress.

\footnotetext{
${ }^{1}$ Technical University of Košice, Faculty of Aeronautics, Department of Flight preparation, Košice, Slovakia, palo.petricek@gmail.com, pavol.petricek@tuke.sk

${ }^{2}$ Technical University of Košice, Faculty of Aeronautics, Košice, Slovakia, stanislav.szabo@tuke.sk

${ }^{3}$ Technical University of Košice, Faculty of Aeronautics, Department of Flight preparation, Slovakia, robert.rozenberg@tuke.sk
} 
Table 1: Education services of pilot preparation

Situational Leadership Theory is really the short form for "Hersey-Blanchard Situational Leadership Theory" (1969) and draws major views from contingency thinking. As the name implies, leadership depends upon each individual situation, and no single leadership style can be considered the best. For Hershey and Blanchard, tasks are different and each type of task requires a different leadership style

The specific aspects of situational management application in the technical systems environment are found in Madarász (2003) Situational management methodology and its application

According to Leigh (2019) the situational leadership refers to when the leader or manager of an organization must adjust his style to fit the development level of the followers he is trying to influence. With situational leadership, it is up to the leader to change his style, not the follower to adapt to the leader's style. In situational leadership, the style may change continually to meet the needs of others in the organization based on the situation

The basic acts of civil and military aviation law for pilot education, the acts which are the base for the described process of pilot training at the national and international level

Aviation knowledge, research and subjects according to the Annex I - Part FCL, Syllabus of theoretical knowledge for the Air Transport Pilot Licence, Commercial Pilot Licence and Instrument Rating (EASA, 2016)

Aviation knowledge, research and subjects according to the Commission Regulation (EU) 2015/340 (EASA, 2015), laying down the technical requirements and administrative procedures relating to the air traffic controllers' licences and certificates

Aviation knowledge, research and know-how concentrated within the PEGASUS consortium of aerospace engineering universities and faculties in the EU https://www.pegasus-europe.org/ (Delft, 2007

The know-how, the past and present Civil and Military aviation maintenance, repair and operation's experience

Source: Authors

Selected theoretical framework of the Knowledge Alliance within the Simulation and modelling of Security issues is in the work of Fuchs et al. (2010) focused on the simulation of dangerous substances outflows into the environment because of traffic accidents by dangerous substances transport; in the study by Dvorak et al. (2010) on the enhancing of security on critical accident locations using telematics support; in the work of Balatka et al. (2011) on the exposure of the environment and surface water by dangerous liquid - the slop outflow model; in the study by Kelemen and Blišstanová (2014) on applied knowledge in logistic modelling to handle the threat of floods with aviation logistic support; or in the study by Kompis et al. (2011) on parallel computational models for composites reinforced by CNTfibres for personal and vehicle protection materials; also in the work of Vágner and Papová 2014) on the comparison of Radar Simulator for Air Traffic Control used also for the education of new Air Traffic Controllers; in the work of Pavolová and Tobisová (2013) on the model of supplier quality management in the transport company applied for the air transport; or Kelemen et al. (2018) on the security management and cybersecurity in the air transport; or in the study by Kuzma et al. (2016) on the use of the CAX System as a tool for modeling construction elements in the aviation industry; or in the work of Fözö et al. (2009) on advanced anytime control algorithms and the modeling of turbojet engines etc.

Selected theoretical framework of the Knowledge Alliance within the Applied Technical Sciences is in the work of Nečas and Kelemen (2009) on the call for more security by the technology revolution; in the work of Bučka and Kelemen (2009) on the analysis of the specific requirements related to the Slovak Air Force; in the book by Hovanec (2016) on the digital factory as a prerequisite for successful application in the area of ergonomics and the human factor; in the study by Andoga et al. (2018) on the intelligent situational control of small turbojet engines; in the work of Draganova et al. (2017) on the non-stationary noise analysis of magnetic sensors using allan variance; in the study by Semrad et al. (2014) on the analysis of all composite wing design containing magnetic microwires etc.

Selected theoretical framework of the Knowledge Alliance within the Applied Civil and Military / Air Force management, education and training is in the work of Socha et al. (2016) on the training of pilots using a flight simulator and its impact on piloting precision; in the work of Kelemen et al. (2011) on the situational control methods of the Aviatic didactic flight safety regulations system; in the study by Rozenberg et al. (2016) on the critical elements in piloting techniques in aerobatic teams, in the work of Durco et al. (2017) on the means of using CPDLC with ATC procedures in a terminal maneuvering area, in the study by Nečas et al. (2009) on information operations and media: Beyond the Security Scope, in 
the analysis by Kalavsky et al. (2015) on the conditions for abandonment out of a helicopter by using a personal rescue parachute, in the work of Sopoci et al. (2009) on the Air Force knowledge within the Military Management in the 21 century and the Transformation of Army, or as in Szabo $(2018,2019)$ etc.

The educational and research sources for more detailed study are available at the university library or in on-line open access / e-learning modules, and in the future within the MOOC Massive Open Online Courses. The perspective Expert Database of Civil and Military Aviation Experience is still in progress.

\section{Identification of the problem and methodology}

The main problem is the situational management application of new education and training of pilots within the Knowledge Alliance of Aviation Education as the State-Privat Partnership Education Service in the conditions of the Slovak Republic. Aviation education has a much wider meaning than just the education and training of pilots.

The solved issue follows the first part of the study called THE KNOWLEDGE ALLIANCE AS AN EDUCATION SERVICE: UPDATED CONTENT OF INTEGRATED FLIGHT PREPARATION AND TRAINING OF PILOTS.

When analyzing the phenomenon during the second part of study, we used the tools of analysis and synthesis, the method "per partes" (integration in parts) with the potential to apply the situational management method in the aviation practice.

The historical analysis of the management styles of flight preparation and pilot training was carried out on the data basis of the institutions from 1959 until the present day in the Table 2.

The lessons learned from the historical analysis were compared with the findings gained by the expert method. The expert group consisted of 5 specialists experienced in the management of aviation education and pilot training. The data were obtained within the interviews with the experts.

The situational management is a real-time management system in which we get to the required state from the identified state of the system after the deviation from the plans (an emergency or critical situation, etc.), based on information orders for corrective actions (an action intervention) restore the state of a system (subsystem) or its component.

This article represents the area of pedagogical research in the study and scientific field Transport in the Air Transport subgroup. Data collection for the study of the second issue was carried out during $2018 / 2019$. The origin of the analyzed material is in the database of 60 years of aviation education within the Czechoslovakia and the Slovak Republic. Our national experience, including personal experience, has been compared and complemented by the successful experience of aeronautical training abroad. In 2018, the training of foreign pilots began as a part of the state-private educational service in Slovakia. The Faculty of Aeronautics of the Technical University in Košice is a part of this international educational consortium based in Košice. These new findings have affected the results presented in the article, in our study.

\begin{tabular}{|l||}
\hline \multicolumn{2}{|l|}{ Table 2: Institutions } \\
\hline Vojenské letecké účilište Košice (Military aviation school in Košice, Slovakia) \\
\hline Vojenská stredná škola letectva v Košiciach (Military Hight School in Košice, Slovakia) \\
\hline $\begin{array}{l}\text { Odborná výcviková škola letectva Košice (Professional Training School of Air Force Košice, } \\
\text { Slovakia) }\end{array}$ \\
\hline $\begin{array}{l}\text { Vysoká vojenská letecká škola SNP v Košiciach (Military Aviation College of Slovak National } \\
\text { Uprising in Košice, Slovakia) }\end{array}$ \\
\hline $\begin{array}{l}\text { Vojenská letecká akadémia gen. Milana Rastislava Štefánika v Košiciach (Air Force Academy of } \\
\text { Gen. M. R. Šefánik in Košice, Slovakia) }\end{array}$ \\
\hline $\begin{array}{l}\text { Letecká fakulta Technickej univerzity v Košiciach (Faculty of Aeronautics, the Technical } \\
\text { University of Košice, Slovakia) }\end{array}$ \\
\hline Lotnicza Akademia Wojskowa - "Szkoła Orląt" (Air Force Academy in Deblin, Poland) \\
\hline $\begin{array}{l}\text { Univerzita obrany, Fakulta vojenských technológií, the Czech Republic (University of Defence, } \\
\text { Faculty of Military Technology, teh Czech Republic) }\end{array}$ \\
\hline École de l'air, Salon-de-Provence, France (French Air Force Academy) \\
\hline Source: Authors \\
\hline
\end{tabular}




\section{Results and Discussion. Presentation of situations}

The Integrated Flight Preparation and Training System functions as a comprehensive, professional training of specialized aeronautical personnel to carry out the specified flight tasks at an acceptable level of flight safety with the required final quality of the preparation and training process, with the maximum efficiency of the human, material, technical and financial resources used.

Implementation of the target function of the system is generally ensured through the steady practice of the following partial system management functions: planning function, operational function, monitoring function, a reaction function, and a coordination function.

For the creation of specific algorithmic and programmable units, it is generally desirable to perform a further decomposition of partial control functions according to the expert knowledge: operational situations, time factor, an organization's management hierarchy (an integrated flight training and pilot training system).

Under the conditions of the Slovak Republic, the joint aviation education of the civilian and military aviation personnel is again implemented from the academic year 2016/2017. The executives are the authorized state, public and private entities that make up the Knowledge Alliance of Aviation Education, which is actively involved in the creating a professional description of the integrated study field Transport. This issue presents another separate article.

The Knowledge Alliance of Aviation Education is a consortium of authorized state, public and private entities that are oriented towards the training of personnel for the pursuit of professions and licensed activities in Civil and Military Aviation, the air transport and space vehicles in transport, in the design, maintenance, operation of relevant technologies in particular modes of transport, in the transport services, according to the relevant international and national standards / regulations.

The Location of integrated flight preparation and training of pilots in the training system of the Armed Forces of the Slovak Republic / the Knowledge Alliance:

The structural changes in the Armed Forces have led to fundamental changes in the philosophy and access to an overall training management system that will allow the commanders to achieve and maintain a degree of operational readiness and subordinate the training in which they retain the ability to perform the tasks they are assigned.

The new way of managing training is based on the economical use of all available sources of air training and air defense, which is the priority employment of troops and forces of the Slovak Armed Forces (Air Force) at peacetime, implemented by the commander of the Air Force of the SR within the integrated management training system.

The combined mission-based training and specific requirements for an airplane, rocket, or the support unit will allow the subordinate units (high-power, low-power, long-term forces) to be kept at a high level of readiness. The effectiveness of military air force training, with an emphasis on an acceptable level of flight safety and on the training safety, is the basis for the actual implementation of centralized planning and decentralized training based on the established principles in the internal service regulations of the armed forces.

The Commander of the Slovak Air Force for implementation of the training management system allocates the specific training resources in the process of planning, coordination, execution and evaluation of training and issues training orders to the subordinate commander of blocks and units of the Slovak Air Force.

The order of the Slovak Air Force commander for the training (the Air Force commander's training instruction for the relevant years), as the most important document in the framework of the Armed Forces Training System, outlines the objectives and training priorities, sets of standards and source constraints of the combined arm and the aviation training of subordinate troops and services presented a vision of the training direction. The issued training regulation is updated, as a rule, every 6 months, in order to optimize and update the required training. We assume the use of this action to specify the results of unit training and to eliminate any inaccuracies that are an objective accompanying phenomenon of the armed forces training process. The combined arm preparation of aviation personnel, technical personnel and air, rocket and support specialists of the Air Force of the SR respects the combat training programs of the Air Force Staff. The flight training, emergency flight training, security and protection 
of air operations of airplanes and helicopters are carried out on the Wing of the General Air Force of Otto Smik in Sliac, the Air Wing of General Colonel Jan Ambrus in Presov, and in the Transport Air Wing at Kuchyna Airport.

Figure 1: Model of structure and management of the complex within the Slovak Air Force / the Knowledge Alliance

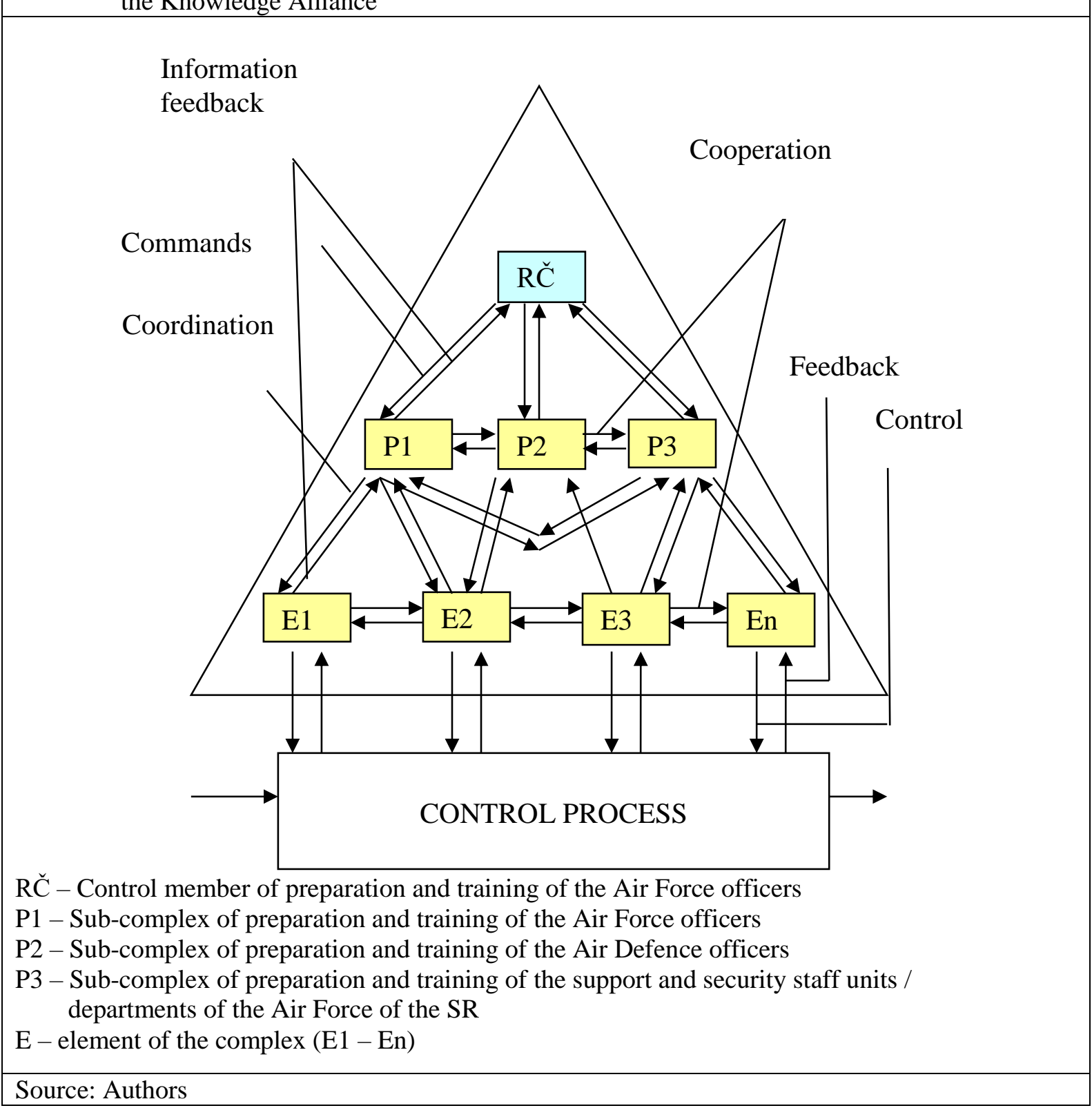

The determination of the place of integrated flight preparation and training of the Air Force pilots of the Armed Forces of the Slovak Republic results from the intentions of using the individual components of the armed forces. The integrated flight preparation and pilot training is an integral part of the overall Armed Forces Training Management System, which contributes to achieving the required operational readiness of blocks and services, implementing aeronautical training in accordance with the training objectives, according to defined and derived combat tasks of the air units. The integrated flight preparation and training of pilots is a part of the preparation and training complex of the Air Force members of the Slovak Armed Forces managed by the Commander of the Air Force of the SR with a different combination of management types. One of the models of management of the mentioned complex may be represented in Figure 1.

The situational management of the complex takes the form of direct orders and the professional regulations during the four training periods of the calendar year (see Figure 1). 
The impact of the external environment on the complex as well as the availability of human, material, technical, and financial and training resources for the implementation of the complex function are respected in accordance with the goal-oriented activity (function) of all elements.

Evolutionary management creates prerequisites for the non-stationary nature of the preparation and training complex of the Air Force of the SR, creating a target-oriented, safe, high-quality and efficient complex. The Commander of the Air Force of the SR determines (issues) his control commands as part of the planning activity during the preparatory period of the training year, in the form of master planning documents for the preparation and training of personnel.

Cooperative management respects the general purpose of complex management functions, as well as the partial objectives and functions of the sub-complexes set by the Commander of the Air Force of the SR. The sub-complexes have autonomy in the decision-making and action, but also use collaboration with other subcomponents. They use information about the status of the complex, the external environment, and the activities of the cooperative subcomponents whose analysis forms the basis for their own decision-making processes and management commands, within the framework of decentralized management to achieve the common goal of the complex. The cooperative management of the P1 subcomponent - the preparation and training of Air Force members of the SR is carried out by the members of the Command Operations and Training Section of the Air Force in Zvolen within the planning and situational management.

\section{Conclusion}

The management strategy represents a set of alternatives resulting from the decision-making processes. From the chosen strategy, the outcome of the management process depends upon the influence of the external conditions on the system (element of the system), the decision maker's activity (or the team of decision-makers) and the influence of an indeterminate factor (unforeseen circumstances) in the given environment.

Determining the purpose of the process and choosing a set of assessment criteria for assessing the system is and remains, according to the experts, the exclusive area of human activity.

Situational management is a real-time management system in which we get to the required state from the identified state of the system after deviation from the plans (an emergency or a critical situation, etc.) occurs, based on information orders for the corrective actions (an action intervention) restore the state of a system (subsystem) or its component.

The concept of situational management, in accordance with the system approach to the flight preparation and training of pilots, as a curricular aviation education of pilots, may also be applicable in military and civil aviation for pilots with a different level of competences, independently of the role or the business intention of the subject.

This article meets the main goal of pedagogical research to create a proposal for the application of situational management of the Knowledge Alliance of Aviation Education as the State-Privat Partnership Education Service in the conditions of the Slovak Republic for the realization of goals in the field of education and training of Air Force Pilots of the Slovak Armed Forces.

On the basis of the results and our personal experience we can state that situational management is the optimal tool of the education and training of pilots. We can use the following control processes: commands, control, coordination, cooperation and feedback for the efficient management of education and training of pilots as a complex aviation system. The aviation systems are the systems where people work together with technical devices. The main sources of knowledge and good practice in the management of education and training of pilots are within our national experience of 60 years of aviation education, the experience of our NATO Partners and the PEGASUS consortium of Aerospace Universities and Faculties in Europe. Aviation education has a much wider meaning than just the education and training of pilots.

\section{Acknowledgements}

This article was prepared in the framework of the institutional project "Integrated Aviation Education of Civilian and Military Personnel at the Faculty of Aeronautics, the Technical University of Košice, SR", in 2019-2020. 


\section{References}

Andoga, R., Fozo, L., Judicak, J., Breda, R., Szabo, S., Rozenberg, R., \& Dzunda, M. (2018). Intelligent Situational Control of Small Turbojet Engines. International journal of Aerospace Engineering, 2018, 1-16. doi:10.1155/2018/8328792

Annex I - Part FCL. Syllabus of theoretical knowledge for the Air Transport Pilot Licence, Commercial Pilot Licence and Instrument Rating, EASA, Brussels, Belgium, 2016. Retrieved from https://www.easa.europa.eu/sites/default/files/dfu/PartFCL.pdf

Balatka, M., Fuchs, P., Kamenicky, J., Sousek, R., \& Kelemen, M. (2011). Exposure of the environment and surface water by dangerous liquid - the slop outflow model. In Sánchez, M. (ed.), 15th World Multi-Conference on Systemics, Cybernetics and Informatics, Proceedings, Volume III, Orlando, Florida, USA, July 19th - July 22nd, 2011, 280-284.

Bučka, P., \& Kelemen, M. (2009). Requirements related to the Slovak Republic's Air Force. In Vintr, Z. (ed..), International conference on Military Technologies, ICMT '09 [electronic source], Brno, Czech Republic, May 5-9, 2009, $282-289$.

Draganová, K., Moucha, V., Volcko, T., \& Semrád, K., (2017). Non-Stationary Noise Analysis of Magnetic Sensors using Allan Variance. Acta Physica Polonica, 131(4), 1126-1128.

Drotárová, J., Kačíková, D., Kelemen, M., \& Bodor, M. (2016). The possibilities of using blended learning in fire safety education. In CBU international conference proceedings 2016: innovations in science and education: March 23-25, 2016, in Prague, Czech Republic. Vol. 4; eds. Tavleen Sahota, Mary-Anne Jones. ISBN 978-80-88042-05-1. ISSN 1805-997X. p. 283-286.

Dvorak, Z., Cekerevac, Z., Kelemen, M., \& Sousek, R. (2010). Enhancing of security on critical accident locations using telematics support. In Sánchez, M. (ed.), International conference on society and information technologies, ICSIT 2010 proceedings, Orlando, Florida, USA, April 6th-9th, 2010, 414-417.

Ďurčo, S., Sabo, J., Rozenberg, R., \& Miženková, Ž. (2017). Means of CPDLC using with ATC procedures in terminal maneuvering area. In Hrubý, M. (eds.), Distance Learning, Simulation and Communication 2017, proceedings, Brno, Czech Republic, May 5-9, 2017, 62-67.

EASA, Commission Regulation (EU) 2015/340 of 20 February 2015, Brussels, Belgium, 2015. Retrieved from https://www.easa.europa.eu/document-library/regulations/commission-regulation-eu-2015340

Fuchs, P., Novak, P., Saska, T., Smida, J., Dvorak, Z., Kelemen, M., \& Sousek, R. (2010). Simulation of dangerous substances outflows into the environment because of traffic accidents by dangerous substances transport. In Sánchez, M. (ed.), the 14th world multi-conference on systemics, cybernetics and informatics, WMSCI 2010 proceedings, volume 1, Orlando, Florida, USA, June 29th - July 2nd, 2010, 204-207.

Fözö, L., Andoga, R., \& Madarász, L. (2009). Advanced anytime control algorithms and modeling of turbojet engines. In Rudas, I.J., Fodor, J. \& Kacprzyk, J. (eds.), Computational intelligence and informatics, the 10th international symposium of Hungarian researchers, proceedings, Budapest, Hungary, November 12-14, 2009, 83-94.

Hovanec, M. (2016). Digital factory as a prerequisite for successful application in the area of ergonomics and human factor. Theoretical Issues in Ergonomics Science, 18(1), 35-45.

Kal’avský, P., Socha, V., Socha, L., Kutílek, P., Gazda, J., \& Kimličková, M. (2015). Conditions for Abandonment Out of a Helicopter Using Personal Rescue Parachute. In Stefek, A. \& Krivanek, V. (eds.), International Conference on Military Technologies Location, Book Series: International Conference on Military Technologies, Brno, Czech Republic, MAY 19 21, 2015, 467-471.

Kelemen, M., \& Blišt'anová, M. (2014). Logistic Modelling to handle the Threat of Floods - The Bodva River example. In Curran Associates, Inc. (eds.), 14th International Multidisciplinary Scientific GeoConference, SGEM 2014 Conference Proceedings, Volume III, Sofia, Bulgaria, June 17-26, 2014, 715-723.

Kelemen, M. (2017). Security of the Slovak Republic and issues of protected interests: Security and criminal law research topics. In Fire protection, Seafety and Security 2017. International Scientific Conference Proceedings, May 3rd. - 5th., 2017, Zvolen, Slovak Republic. Editors Majlingová, A, Vel'ková, V. Zvolen: Technical university, 2017. ISBN 978-80-2282957-1. 312-316.

Kelemen, M., Nečas, P., \& Terem, P. (2010). Advanced aerospace management of integrated education and training towards comprehensive security. Incas Bulletin, 2 (3/2010), 45-49.

Kelemen, M., Nečas, P., Bučka, P., \& Boscoianu, M. (2011). Situational control methods of Aviatic didactic flight safety regulations system. In A ZMNE KLHTK tudományos folyoirata, 4 (1/2011), 18-21.

Kelemen, M., Szabo, S., \& Vajdová, I. (2018). Cybersecurity in the Context of Criminal Law Protection of the State Security and Sectors of Critical Infrastructure. In CNDCGS 2018 International Scientific Conference, 25.04.2018-27.04.2018, Litva. SIGN-TUKE 197361 // Challenges to national defence in contemporary geopolitical situation: proceedings / Bekesiene, S. (editor); Hošková-Mayerová, Šárka (editor). - Vilnius (Litva): The General Jonas Žemaitis Military Academy, 2018. ISSN (online) 2538-8959. 100-104.

Kelemen, M., Szabo, S., \& Vajdová, I. (2018). Security Management in the Air Transport: Example of an Interdisciplinary Investigation of Special Security Questions. In CNDCGS 2018 International Scientific Conference, 25.04.2018-27.04.2018, Litva, Challenges to national defence in contemporary geopolitical situation: proceedings / Bekesiene, S. (editor) ; HoškováMayerová, Šárka (editor). - Vilnius (Litva): The General Jonas Žemaitis Military Academy, 2018. ISSN (online) 2538-8959. 105-108.

Kelemen, M., Pilát, M., Makó, S., Rozenberg, R., \& A. Tobisová (2019). Pricing Policy Aspects in Competitive Fight Between Low-Cost Airlines on Kosice Airport. Journal of Konbin, Vol. 49, 1(2019), 331-342. doi:10.2478/jok-2019-0017 
Kompis, V., Qin, QH., Fu, ZJ., Chen, CS., Droppa, P., Kelemen, M., \& Chen, W. Parallel computational models for composites renforced by CNT-fibres. Engineering Analysis with Boundry Elements, Vol. 36, 1/2012, 47-52.

doi:10.1016/j.enganabound.2011.04.009

Kuzma, D., Korba, P., Hovanec, M., \& Dulina, L. (2016). The Use of CAX System as a Tool Modeling Construction Element in the Aviation Industry. Naše more, 63(3) SI, 134-139.

Madarász, L. (2003). Metodika situačného riadenia a jej aplikácie [Situational management methodology and its application]. Kosice, Slovakia: ELFA.

Nečas, P., \& Kelemen, M. (2009). Call for more security: Technology revolution wanted. In in Vintr, Z. (ed.), International conference on Military Technologies, ICMT '09 [electronic source], Brno, Czech Republic, May 5-9, 2009, 246-250.

Nečas, P., Kelemen, M., \& Sopóci, M. (2009). Information operations and media: Beyond the Security Scope? In Stanciu, L. (ed.), $15^{\text {th }}$ International Conference the Knowledge-based Organization: Military Sciences. Security and Defence, Conference Proceedings 1, Sibiu, Romania, November 26-28, 2009, 96-103.

Pavolová, H., \& Tobisová, A. (2013). The Model of Supplier Quality Management in Transport Company, Naše more, 60 (5/6), 123-126.

Petlák, E. (2004). General Didactics. Bratislava: Martinus.

Polishchuk, V., \& M. Kelemen. (2019). Information Model of Evaluation and Output Rating of Start-up Projects Development Teams. In Luengo, D. et al. (ed.) Proceedings of the Second International Workshop on Computer Modeling and Intelligent Systems (CMIS-2019), Zaporizhzhia, Ukraine, April 15-19, 2019. CEUR Workshop Proceedings Vol. 2353, CEUR-WS.org 2019, 674-688. Retrieved from http://ceur-ws.org/Vol-2353/paper54.pdf

Polishchuk, V., Kelemen, M., \& Kozuba, J. (2019). Technology Improving Safety of Crowdfunding Platforms Functioning in the Context of the Protection of the Start-Up Investors in the Financial and Transport Sectors. Journal of Konbin, Vol. 49, 1(2019), 313-330. doi:10.2478/jok-2019-0016

PEGASUS consortium of Aerospace Engineering Universities, Delft., Netherlands. Retrieved from https://www.pegasuseurope.org/

Rozenberg, R., Socha, V., Socha, L., Szabo, S., \& Němec, V. (2016). Critical elements in piloting techniques in aerobatic teams. In Ostaševičius, V. (ed.), Transport Means 2016 - Proceedings of the International Conference, Kaunas, Lihuania, October 5-7, 2016, 444-449.

Sample of Field Description. (2008). Bratislava, Slovakia: Ministry of Education, Science, Research and Sport, 2008.

Semrád, K., Lipovský, P., Cernan, J., \& Jurčovič, M. (2014). Analysis of all composite wing design containing magnetic microwires. In Trebuňa, F. (ed.), Modelling of Mechanical and Mechatronic systems, $6^{\text {th }}$ Conference on Modelling of Mechanical and Mechatronic systems (MMaMS), Vysoké Tatry, Slovakia, November 25-27, 2014, 428-434.

Socha, V., Socha, L., Szabo, S., Hanak, K., Gazda, J., Kimlickova, M., Vajdova, I., Madoran, A., Hanakova, L., Nemec, V., Puskas, T., Schlenker J., \& Rozenberg, R. (2016). Training of pilots using flight simulator and its impact on piloting precision. In Ostaševičius, V. (ed.), Transport Means 2016, Proceedings of the International Conference, Kaunas, Lihuania, October 5-7, 2016, 374-379.

Sopóci, M., Kelemen, M., \& Nečas, P. (2009). Military Management in 21 century and Transformation of Army. In Stanciu, L. (ed.), $15^{\text {th }}$ International Conference the Knowledge-based Organization: Military Sciences. Security and Defence, Conference Proceedings 1, Sibiu, Romania, November 26-28, 2009, 138-142.

Turek, I. (2004). Innovation in Didactics. Bratislava: MPC, 2004.

Vágner, J., \& Pappová, E. (2014). Comparison of Radar Simulator for Air Traffic Control. Naše more, 61(1-2), 31-35. 